\title{
miR-500a-3p is a Potential Prognostic Biomarker in Hepatocellular Carcinoma [Corrigendum]
}

\author{
Long J, Liu B, Yao Z, et al. Int J Gen Med. 2022;15:1891-1899
}

The authors have advised there is an error in the correspondence section on page 1891. The correct correspondence details are "Chunlin Jiang, jiangc1565885@163.com; Shi Fang, fangshi@mail.sysu.edu.cn".

\section{Publish your work in this journal}

The International Journal of General Medicine is an international, peer-reviewed open-access journal that focuses on general and internal medicine, pathogenesis, epidemiology, diagnosis, monitoring and treatment protocols. The journal is characterized by the rapid reporting of reviews, original research and clinical studies across all disease areas. The manuscript management system is completely online and includes a very quick and fair peer-review system, which is all easy to use. Visit http://www.dovepress.com/testimonials.php to read real quotes from published authors. 